\title{
Perceptions and Challenges to ICT Use in ESL Lessons among Malaysian Primary Teachers
}

\author{
Michelle Ng, Melor Md Yunus \\ Faculty of Education, Universiti Kebangsaan Malaysia, Bangi, Selangor, Malaysia \\ Email: michellecatherynna@gmail.com
}

How to cite this paper: Ng, M., \& Yunus, M. M. (2021). Perceptions and Challenges to ICT Use in ESL Lessons among Malaysian Primary Teachers. Creative Education, 12, 1532-1557.

https://doi.org/10.4236/ce.2021.127117

Received: June 9, 2021

Accepted: July 6, 2021

Published: July 9, 2021

Copyright (c) 2021 by author(s) and Scientific Research Publishing Inc. This work is licensed under the Creative Commons Attribution International License (CC BY 4.0).

http://creativecommons.org/licenses/by/4.0/

(c) (i) Open Access

\begin{abstract}
In light of society's progressive adoption of Information and Communication Technology (ICT), $21^{\text {st }}$-century teachers are expected to integrate technology into language teaching in the classroom successfully. Nevertheless, despite the availability of existing materials on the internet and ICT facilities provided by the Malaysian government to aid the CEFR lessons, English Second Language (ESL) teachers' perception should consider ICT use in the ESL lessons. Additionally, past researchers also have discovered challenges to ICT use among ESL teachers. This study, conversely, explores whether there is a significant relationship between primary teachers' perceptions of the impact of ICT integration on teaching CEFR level one (Primary One, Primary Two and Primary Three) classes before and after MCO. This study also investigates the challenges that might influence teachers' attitudes toward integrating ICT into their level one (Primary One, Primary Two and Primary Three) CEFR lessons to develop ICT skills and competencies. This study used a mixed-method approach, with the survey method as the research design. It is also embedded within two theories: The Technology Acceptance Model (TAM) and the Theory of Planned Behavior (TpB). An online survey questionnaire was distributed to all participants. The study involved 55 Malaysian primary ESL teachers in Lawas, Sarawak, Malaysia. Therefore, the result cannot generalize to all English teachers in Malaysia. Based on the findings, the study results indicate that the null hypothesis-there is no relationship between Malaysian primary teachers' perceptions of the impact of ICT use in their level one (Primary One, Primary Two and Primary Three) CEFR lessons before MCO and after the MCO period, cannot be rejected to a certain extent. The study also discovers four main challenges to ICT Use in ESL (CEFR) Lessons: lack of ICT infrastructure and basic facilities, teachers' attitude, pupils' engagement, and parents' ability. This study can give a relevant picture to policymakers and the Ministry of Education on the current state of ESL teachers' perception and challenges regarding ICT use in ESL (CEFR) lessons. With
\end{abstract}


thorough analysis, it is hoped that the government can develop a win-win situation for ESL teachers and their students in the rural areas, especially when remote teaching-learning is implemented primarily during the MCO period.

\section{Keywords}

Information and Communication Technology, Perception, Challenges, English Second Language Lessons, Malaysian Primary Teacher

\section{Introduction}

In the education field integration of Information and Communication Technologies (ICTs) among the teachers is probably turning into a norm as it is believed that ICTs in education can change teaching. Eventually, the implications of ICTs are constantly experienced in classrooms. According to Poudel (2018), teaching is dependent on the gradual integration of ICTs. With the progressiveness of ICTs usage among society, $21^{\text {st }}$-century teachers are expected to integrate technology into teaching languages in the classroom successfully. Undeniably, considering the expectation of the positive vibes and the complications (internal and external factors) that could contribute to teachers' expectations and motives to incorporate ICTs into their language classrooms is a vital aspect. The aspect ensures that the school could achieve the aspiration highlighted explicitly by the education department to include them.

In Malaysia, English is applied chiefly in commerce, trading, engineering, medical, and education due to globalization's impact. In short, English is a second language in organizations, social affairs and education. As for education purposes, English is taught as a second language officially in schools nationwide, specifically the government schools. The Malaysian Government strives to leave behind in education as we progress towards becoming a more competitive society-the educators and teaching approach to changes over time. Therefore, allocating the fund for education under Malaysian Ministry of Education continuously becomes the top priority to ensure there is a progression towards upgrading the school facilities, syllabus, management and students welfare. In Malaysia, changes start in the classroom, where technologies such as projectors, laptops and wireless internet are being implemented (Yunus, 2018). Moreover, Malaysian Ministry of Education has established guidelines for the implementation of teaching and learning for the Movement Control Order (MCO) period with the aims to determine the scope of practice of administrators, teachers, parents and students in making sure the quality of teaching and learning (Bernama, 2020).

When it comes to ICTs integration in the English language classrooms, the initiative by Malaysian Ministry of Education is revising the schools' English syllabus curriculum to the current CEFR-aligned curriculum. The term CEFR 
stands for Common European Framework of Reference for Languages. The curriculum started in 2017, beginning at the pre-school level, the primary level-primary level 1 and primary level 2 and the secondary level-form 1 and form 2 pupils are its pioneers. In other words, by having the revised version of the curriculum, the English teachers are given the privileges to undergone CEFR training and courses conducted by trained Master Trainers across the stages. It started with the training under the national level with the Cambridge English trainers (experts) to the state level, and then passed down to the district level and finally to the respective schools.

The latest features of the CEFR-aligned syllabus' textbooks provided by Malaysian Ministry of Education come with CD-ROM consists of audios for listening activity and QR codes along with attractive visuals. The advancement of social media such as e-mails, Facebook, WhatsApp, Telegram, YouTube, and Blogger is also seen as an alternative for English teachers to look for extra materials related to the current CEFR-based lessons and syllabus learners' age group and level of schooling. The availability of materials appears to be usable by both teachers and students all over the world. Nevertheless, the study aims to answer these two questions. 1) Is there any significant relationship between the Malaysian primary teachers' perceptions of ICT use in the ESL (CEFR) level one (Primary One, Primary Two and Primary Three) lessons before MCO and after the MCO period? 2) What are the challenges the Malaysian primary teachers face on ICT use in the ESL (CEFR) level one (Primary One, Primary Two and Primary Three) lessons before MCO and after the MCO period?

In short, this study discovers the Malaysian Primary English Teachers' point of view regarding the impact of ICT use in the current Malaysian curriculum in terms of perception and challenges, stimulated by the Technology Acceptance Model (TAM) and the Theory of Planned Behavior (TpB). It also adds the value of ICT use in the language lesson based on two scenarios: before implementing MCO and MCO implementation.

\section{Literature Review}

\subsection{The Importance of ICT in Education}

The ICT revolution has raised education to a new level, resulting in the integration of ICT into various fields and industries, which has become an indirect goal for the majority of countries around the world. In a more precise picture worldwide, it is observed that even the learning process in school from time to time has changed from only using the "chalk and talk" strategy to a communicative approach in language teaching. Parra (2012) points out the teacher's role is impacted by the limitless impact of technology. It is also influencing part and partial of daily school life. Kadian et al. (2019) also highlight the shift in the teacher's role from knowledge provider to facilitator in a technology-assisted or virtual classroom. In the past, the "chalk and talk" strategy was commonly used by teachers to deliver learning content or information to students. However, at 
present, the method where knowledge is gained, achieved and construed has transformed due to the revolution of ICT (Aguilar, 2012; Hernandez, 2017). This scenario may arise as a result of teachers incorporating ICT equipment into their teaching and learning processes.

Several aspects determine teachers' use of technologies for learning. The aspects comprise positive perceptions that refer to factors that lead to their use and negative perceptions that refer to elements that discourage their usage (Silviyanti \& Yusuf, 2015). The Technology Acceptance Model (TAM) was used in several previous studies on technology adoption aimed at person's acceptance of technology (Alshare et al., 2009; Baker-Eveleth et al., 2006; Davis et al., 1989; Davis \& Wong, 2007; Emad et al., 2016; Goeke \& Faley, 2007; Ha \& Stoel, 2009; Kim \& Bonk, 2006; Lin, 2008; Lin \& Chou, 2009; Zaremohzzabieh et al., 2015). The Technology Acceptance Model (TAM) suggested that persons' states of mind towards another technology depend on the two key elements: Perceived Usefulness (PU) and Perceived Ease of Use (PEoU).

Ajzen (1988) envisioned the concept of the Theory of Expected Behaviour (TpB) to Ajzen \& Fishmein (1980) expanded version of the Theory of Reasoned Action (TRA). There is a significant difference between TpB and TRA. TpB is used only for behaviours controlled by an individual, while TRA sees volitional control as a variable (Knabe, 2012). Past researchers have applied TpB to technology-related studies and behaviour related to the Internet (Baker \& White, 2010; Fortin, 2000; George, 2002; Knabe, 2012; Lee et al., 2010; Moss et al., 2010; Robinson \& Doverspike, 2006). Ajzen (2000) has reformulated the TpB, which is shown in Figure 1.

According to Ajzen (2019), Behavioral Beliefs mean the contextual possibility that the Behavior produces a result or experience. Behavioral Beliefs have a connection with the Attitude toward the Behavior (AAct). AAct refers to the extent to which conduct efficiency is measured positively or negatively. Normative beliefs correspond to perceived behavioral perceptions of such significant individuals or classes of reference as the partner, family, friends and instructor, doctor, boss, and colleagues, depending on the population and actions examined. Normative beliefs have a connection with the Subjective Norm (SN). SN relates directly to a viewed contractual obligation to partake in Behavior or not. Control

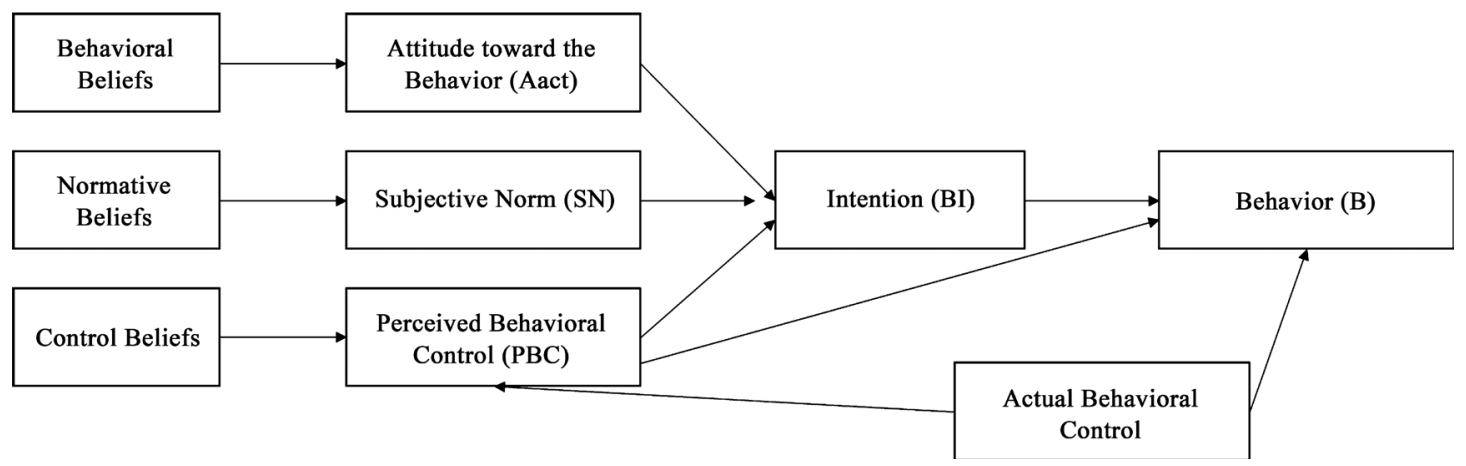

Figure 1. Theory of planned behavior by Ajzen (2000). 
Beliefs deal with the perceived existence of aspects that may promote or impede behavioral performance. Perceived Behavioral Control influences control Beliefs (PBC). $\mathrm{PBC}$ relates to the perceived people's capacity to perform a specific behavior. AAct, $\mathrm{SN}$ and $\mathrm{PBC}$ can lead to Intention. The Intention is observed focused on the behavioral Attitude and subjective norm, each weighted by its importance to actions and population of interest-their effect on perceived behavioral regulation. PBC, Intention and Actual Behavioral Control might control the outcome of the Behavior. Behavior refers to the demonstrable, observable reaction regarding a target in a situation. It acts as a role of compatible behavioral regulation expectations and perceptions. Actual Behavioral Control also might affect the PBC. Actual Behavioral Control reflects the degree whereby a user possesses the skills, resources and several requirements for performing the Behavior.

\subsection{Teachers' Perception on ICT in ESL Learning Activities}

In line with the seventh shift in the Malaysia Education Blueprint 2012-2025, the Malaysian government has taken steps to prepare schools by upgrading ICT facilities in classrooms such as computers, laptops, and projectors in collaboration with non-governmental organizations (NGOs). The initiative aims to improve classroom learning quality by leveraging ICT. Ismail (2019) reports that internet connection services to all the schools will be provided by three major providers from the private limited companies: Telekom Malaysia Berhad, Celcom Axiata Berhad and Maxis Broadband Sendirian Berhad starting from June 1, 2019. In a way, establishing the ICTs is the stepping stone to satisfy the needs of a learning environment of the 21 st century.

Due to the Malaysian government's measurement, it is believed that it could positively impact classroom learning activities in ESL teaching and learning practices. In other words, it could transform the ESL lessons into a livelier setting or circumstances. By turning the environment into learner-centred learning and encouraging deep learning, using multiple alternatives provided by ICTs will improve teaching and learning (Mbodila et al., 2013). Both teachers and ESL students will benefit and increase the opportunity to accept and instill ICT implementation with ease. Most importantly, teachers' perception and understanding of educational innovation influence their actions, decisions, and classroom practices (Rusdin, 2018). Besides, based on the TpB model by Ajzen (2000), government assistance in upgrading ICT facilities, particularly the Internet, may influence the control belief of the perception and the intention of English teachers to use ICT in their ESL classrooms.

In general, teachers in the twenty-first-century classroom are expected to facilitate student learning and create productive classroom environments. Students can develop the skills they will need in the future, including ICT skills. Rohaan et al. (2008) emphasize teachers' attitudes towards technology and teaching in technological education reflected an aspect of teachers' attitudes that influences students' attitudes and teachers' professional knowledge. On the other hand, a 
study by Muslem et al. (2018) has discovered that the teachers have positive views on ICT use in the classroom and its essential values for society. Yet, they all believed that technology could not replace their role in teaching English because ICTs cannot provide direct immeasurable emotional influence on students such as encouragement, support, safety, character, and inspiration.

The effort made by teachers to manage ICT in their classrooms would increase the motivation and involvement of their students. According to Leong et al. (2019), the learners were interested in and motivated to learn vocabulary using the digital storytelling application, which provided thorough guidance, practice, and assessment (hyperlinked vocabulary notes, multimodal glosses, and vocabulary exercises) to ensure the learners learned the vocabulary. Therefore, teachers should take proactive move to tailor their teaching rendering to the motivation of their students.

\subsection{Challenges of ICT Use in Language Activities}

According to Silviyanti and Yusuf (2015), teachers do not effectively use technology in their English Language Teaching (ELT) cycle because not all can use ICT given their ability to provide their teaching practice with significant resources. In short, teachers may well have experience using ICT for their teaching, but they may be limited from using it by inadequate numbers of computers. Teachers would not have been motivated to use ICT in the classroom unless the school had good tools and appropriate educational equipment, including computer software and hardware (Mirzajani et al., 2016). In reality, the scenario is relatively common due to matters that could be overcome through self-awareness among the teachers to ICT use or need extended assistant from the higher authority and shareholders, especially on the accessibility of ICTs facilities and equipment in schools. Most likely, the scenario, as mentioned earlier, has become a conflict of interest since the existent of technology took place and emerged into the education world.

A study conducted in Vietnam regarding ICT usage in English teaching by Pham et al. (2019) discovered four issues and challenges. Among the problems are poor financial conditions for ICT facilities and a shortage of time in class. By looking at the scenario in Malaysia, even with Internet access improving the rating from 87 per cent in 2018 to 90.1 per cent in 2019, due to reasons such as high and low level of confidence in equipment prices, inadequate knowledge and skills to practice it, the remaining underprivileged households were unable to access the Internet at home (Azahar, 2020). Most researchers also report that the most fundamental and essential aspects are the power source and network connectivity. So the least developed countries are forced to concentrate on building ICT-integrated classrooms in urban environments (Cha et al., 2020).

Undoubtedly, each teacher has his or her strength and preference for ESL learning activities' strategies and teaching practices. Nevertheless, the inability to handle ICTs in line with their teaching style and classroom management could 
be why ESL teachers revert to traditional teaching methods, specifically the chalk and talk methods. Yunus et al.'s (2013) reveal that the drawbacks of ICT incorporation in the classroom need to be taken into account, particularly by teachers who are experiencing difficulty, for instance, in-class discipline and interruption. Besides, the real point is that Malaysian rural areas need more time for e-learning to become a reality (Cheok et al., 2017). Habibu et al. (2012) identify eight aspects that limit ICT use in Uganda's teaching and learning process. Among the factors are teachers' reluctance to new technology, lack of skilled personnel, time limitation, lack of confidence, and lack of knowledge. Narinasamy and Wan Mamat (2013) found that the deficiency of time faced in completing the syllabus resulted in discarding the ICT in classroom teaching. By thinking of remaining in a comfort zone and living in denial, this returns to teachers, believing that it is necessary to complete the curriculum syllabus in schools rather than mastering ICT literacy. Nevertheless, when it comes to the level of ICT integration, According to Kamaruddin et al. (2017), the highest mean score for the teachers' ICT integration is 2.68 (activity: prepare lessons and reports). This finding shows that teachers use ICT as a routine for lesson planning and making reports.

Histrionic changes have taken place in the educational world in the teaching method, especially after the Movement Control Order (MCO) imposed on almost all parts of the world due to Coronavirus diseases, commonly known as the COVID-19 Epidemic strike. The number of cases involving people infected with the COVID-19 virus has surpassed 'terrifying' levels, with death cases rising. Based on a World Health Organization (WHO) survey on Countries, Territories or Areas with laboratory confirmed COVID-19 Cases and Deaths as of 27 March 2020 , the overall number of reported cases is 509,164 with 23,335 deaths (WHO, 2020). Therefore, the implementation of remote learning and flipped classroom is seen to be vigorously taken into account by most educational institutions throughout MCO imposition.

In Malaysia, eight million students have been impacted by school closures (Azahar, 2020) due to MCO’s imposition. Malaysian Ministry of Education has ordered teachers to work from home to continue their education through online learning. Nevertheless, Espino-Díaz et al. (2020) discover that one of the consequences of closing schools during the COVID-19 pandemic is the inability of parents to assist their children in completing the homework. Due to the COVID-19 pandemic outbreak, the transition to distance learning was much more troublesome for parents with English language learning than predicted (Maya, 2020). Due to technical errors such as connectivity issues and technical glitches, a third of them do not do the given tasks. The student response has not been very positive because some students do not react or respond (Thomas \& Fong, 2020).

According to Pope (2020), "Homework" varied significantly between March and June 2020. Some schools assigned weekly packets of work to be completed at 
home instead of any online lessons. In contrast, others decided to eliminate "homework" for students who participated in online classes for several hours each day. The study's findings reveal that homework is the most common response from the interview conducted based on the question "Right now in your life, what, if anything, causes you the most stress?" to middle and high school students from high-performing schools. In the Malaysian context, the level of the latest KSSR syllabus, due to Higher Order Thinking Skill (HOTS), is higher than what it should be taught in certain education levels. KSSR refers to the Malaysian National Curriculum for the Primary School level, introduced by Malaysian Ministry of Education in 2011. The new revised KSSR syllabus was later introduced in 2017. It is understood that some parents, particularly the low-educated, may face the difficulty of understanding the content of learning and teaching their children to complete the homework, especially during the MCO period where distant learning was conducted. Both students and parents believe this is a severe problem because they believe the questions were created solely to be used as HOTS issues ("Years of Mismanaged Change in Education Must End", 2018).

Moreover, Juin (2016) states that most Malaysian rural ESL students have low levels of proficiency. The rural students tend to mix, combine, misuse, or apply both rules and linguistic comprehension of the languages into writing without realizing it while learning the second language (Harun \& Abdullah, 2020). As a side effect, guidance from their English teachers is critical for students to complete their homework. They cannot rely on their parents alone, even when they do not have access to the internet to look for homework-related information.

Throughout the MCO period, educators across the nation have taken different measures to overcome the challenges faced by the inability to conduct online learning effectively (Karim, 2020). The Homework Delivery project is one of the actions taken. However, the Malaysian Ministry of Education in the earlier phase generally did not encourage it as part of guidelines detailing the roles and responsibilities of administrators, teachers, parents and students to ensure the smooth delivery of teaching and learning throughout the Movement Control Order (MCO). Earlier, Malaysian Ministry of Education has commanded that it was not permitted to distribute and retrieve printed materials involving movement during the MCO period (Karim, 2020). The move is thought to ensure that teachers and students have as little contact as possible, reducing the risk of another COVID-19 cluster forming across the country.

Nonetheless, the most notable news about the homework delivery project came when an English teacher, Muhammad Nazmi Rosli, also known as Nazmi of SK Long Sukang, Lawas, and his colleagues, initiated the project in early April 2020. They delivered homework to their students to 13 villagers in Sarawak's remote Lawas high-lands (Ling, 2020). Another action taken by SK Long Sukang is the Ruai classroom-small classes in the "ruai" project to ensure the teachers monitor the pupils' home-work project. The word "ruai" is originated in one of 
East Malaysia-Sarawak's native language (the Iban) refers to a covered balcony or veranda. The action taken is driven by Malaysian Ministry of Education's Education For All (EFA) policy, which is fundamental for providing equal access to basic education, according to the Ministry of Education (2015).

Based on those mentioned above, it is necessary to comprehend the challenges and driving factors that may influence their perceptions of ICT use in the educational environment to improve its use.

\section{Methodology}

\subsection{Research Design}

The primary purpose of this research is to explore the Malaysian primary school teachers' perceptions and their challenges on the impact of ICT use in their level one (Primary One, Primary Two and Primary Three) ESL (CEFR) lessons. The researcher used a descriptive survey design to reach the aim. The study employed the mixed method: quantitative and qualitative methods. Multiple data sources can be integrated and synergized in a mixed-methods design, assisting in studying complex problems (Poth \& Munce, 2020). This study applied the Technology Acceptance Model (Davis et al., 1989) and Theory of Planned Behavior (Ajzen, 2000) as the theoretical framework.

\subsection{Population, Participants and Sampling Techniques}

The sample consists of English government primary school teachers from 31 schools who teach CEFR classes (Primary One until Primary Three) in Lawas district, one of the districts located in North Sarawak, Malaysia. One of the prevalent ethnic groups in the field of study (Lawas, Sarawak) is the Lun Bawang, mainly distributed in Limbang districts, such as Trusan, Ba Kelalan, Long Semadoh and Long Luping (Kata Malaysia, 2020). The researchers applied purposive sampling for this research, where 55 teachers were selected as respondents. According to Etikan et al. (2016), purposive sampling, also known as judgment sampling, refers to the intentional choice because of the attributes it possesses. As a result of the sample selected by the researcher, this research was not intended to be generalized and was confined to the intended location of Lawas, Sarawak). Table 1 shows the details on the demographic background of the population:

A total of 55 respondents which comprised 13 male (23.6\%) and 42 female (76.4\%) from two types of school-87.3\% from Sekolah Kebangsaan [Malay-medium National Primary School] and $12.7 \%$ from Sekolah Jenis Kebang-

saan [Non-Malay-medium National-type Primary School] participated in the study. Among these respondents, 48 (87.3\%) are teaching in rural area schools, and $7(12.7 \%)$ are teaching in interior area schools. The highest academic qualification for most respondents (89.1\%) is Degree qualification, followed by SPM [National Examination for Form 5 students or year 11 equivalent in Malaysia]/STPM [Malaysian Higher School Certificate-Malaysian pre-university examination]/Sijil Perguruan Asas [Certificate of Fundamental of Teacher Education] 
Table 1. Demographic background of the population.

Variable: Category

Gender:

Male

Female

Type of school:

Sekolah Kebangsaan

Sekolah Jenis Kebangsaan

School area:

Rural area

Interior area

Highest academic qualification:

SPM/STPM/Sijil Perguruan Asas

Diploma

Degree

Master's Degree

PhD

Teaching experience:

$$
\begin{aligned}
& <5 \text { years } \\
& 5-10 \text { years } \\
& 11-15 \text { years } \\
& 16-20 \text { years } \\
& >20 \text { years }
\end{aligned}
$$

English option?

Yes

No

Available ICT devices in school:

Desktop

Laptop

Portable LCD projector

40

Video recorder

Digital camera

Printer or photocopier machine

Interactive whiteboard

E-books

Other:

i) Speaker, CD ROM

ii) $\mathrm{TV}$

23.6

76.4

1.8

89.1

3.6 


\section{Continued}

\begin{tabular}{lcc} 
Available ICT devices (personal): & & 9.1 \\
Desktop & 5 & 100.0 \\
Laptop & 55 & 96.4 \\
Mobile phone & 53 & 30.9 \\
Tablet & 17 & 20.0 \\
Portable LCD projector & 11 & 3.6 \\
Video recorder & 2 & 10.9 \\
Digital camera & 6 & 80.0 \\
Printer & 44 & 1.8 \\
Interactive whiteboard & 1 & \\
Other: & & 1.8 \\
(i) USB flash drive, Speaker & & \\
Level of internet access in school: & 1 & 5.5 \\
Poor & & 50.9 \\
Average & & \\
Excellent & 24 & \\
\hline
\end{tabular}

qualification with 3 respondents (5.5\%). Next, 2 respondents (3.6\%) come with Masters' Degree qualification, and 1 respondent (1.8\%) comes with Diploma qualification. From the overall population-based on teaching experience, 20 respondents (19.8\%) have $<5$ years of teaching experience followed by 5 - 10 years of teaching experience with 19 respondents (34.5\%), then both $11-15$ years of teaching and $>20$ years of teaching experience with 7 respondents $(12.7 \%)$, and 16 - 20 years of teaching experience with 2 (3.6\%). 32 respondents (58.2\%) are English option and 23 respondents (41.8\%) are non-English option.

In term of availability of ICT devices in school, 44 respondents $(80.0 \%)$ reported that their schools are equipped with portable LCD projector and printer or photocopier machine, followed by a laptop with 40 respondents' (72.7\%), then a digital camera with 7 respondents (12.0\%), a video recorder with 3 respondents (5.5\%), and interactive whiteboard with 2 respondents (3.6\%). Another 2 respondents (3.6\%) have listed other ICT devices: speaker, CD-ROM, and TV. None of the school has E-books.

As for personal ICT devices, all respondents (100.0\%) reported that they have their laptop followed by mobile phone with 53 respondents $(96.4 \%)$, then printer with 44 respondents $(80.0 \%)$. Next, tablet with 17 respondents (30.9\%), portable LCD projector with 11 respondents $(20.0 \%)$, digital camera with 6 respondents (10.9\%), desktop with 5 respondents (9.1\%), a video recorder with 2 respondents (3.6\%), and interactive whiteboard with 1 respondent (1.8\%). Another 1 respondent (1.8\%) has listed other ICT devices: USB flash drive and speaker.

In term of the level of internet access in school, 28 respondents $(50.9 \%)$ reported having an average level of internet access, a low level of internet access 
with 24 respondents (43.6\%), and an excellent level of internet access with 3 respondents (5.5\%).

\subsection{Research Instruments}

Based on questionnaires and collections of interview questions developed by prior researchers, namely Kamaruddin et al. (2017) and Mahdum et al. (2019), a cross-sectional survey questionnaire and open-ended questions were deemed suitable for this study were modified and developed to assess the instrument's reliability. Later, to reinforce the validity of the criterion, the researcher constructed the necessary addition of items in the questionnaire to answer the research questions intended. The online survey questionnaire (created using Google Form) was presented to two expert teachers before the pilot study, and the expert checked the content's validity. The questionnaire was again applied in the actual study to ensure test-retest reliability and internal consistency.

To answer the research questions, data from a survey questionnaire comprising 39 items, including demographic background information, has been used as the primary instrument for the study. The data collected includes both quantitative and qualitative aspects. A questionnaire was presented in Google Form and distributed in which all respondents were required to read the statements and select their answers according to the 4-point Likert scale ( $1=$ Strongly Disagree, $2=$ Disagree, $3=$ Agree, and $4=$ Strongly Agree). The questionnaire consists of three subscales: teachers' perceptions on ICT use in ESL (CEFR) lessons which had 15 items; ICT use in CEFR lessons (Before and After MCO), which had 14 items; and one open-ended question related to challenges faced when using ICT in CEFR lessons.

\subsection{Data Analysis}

The researcher used descriptive statistics (frequency and percentage) and inferential statistics (paired-sample t-test) to analyze the quantitative data. The data collected through questionnaires were analyzed using SPSS version 23 and inferential data (paired sample t-test). The demographic background of the population's data reported as the frequency and percentages data. To identify the relationship between ICT integration before MCO and after MCO, data collected is analyzed to obtain inferential statistics via paired sample t-test. The qualitative data were analyzed using Braun and Clarke's six-step thematic analysis procedure, and its details were also analyzed qualitatively in words based on the respondents' perspectives.

\section{Results}

\subsection{Findings on ICT Use in ESL (CEFR) Lessons (before MCO and after MCO)}

The researcher in the analysis used 14 items to see if there was statistical evidence that the mean difference between Malaysian primary teachers' perceptions 
of the impact of ICT use in their level one CEFR lessons before and after the MCO period was significantly different from zero. The analysis was done using paired-samples T-test, as shown in Table 2. Table 2 shows the result of the paired-samples T-test for the impact of ICT use (before MCO and after MCO).

Hypothesis testing

H0: There is no relationship between Malaysian primary teachers' perceptions on the impact of ICT use in their level one CEFR lessons before MCO and after the MCO period.

H1: There is a significant relationship between Malaysian primary teachers' perceptions on the impact of ICT use in their level one CEFR lessons before $\mathrm{MCO}$ and after the MCO period.

From the data provided in Table 2 on the paired-samples T-test for the impact of ICT use between before MCO and after the MCO period, both sets of data have shown different outcome for each category in terms of statistically significant value at 0.05 level. Out of seven categories, four of the categories have shown there is no statistically significant difference between prepare lessons and reports $(\mathrm{t}=0.187, p=0.855)$, access internet to search teaching materials $(\mathrm{t}=$ $0.727, p=0.470)$, create teaching aids with the computer $(\mathrm{t}=1.181, p=0.243)$, and to make presentation slides/delivery $(t=0.962, p=0.341)$. This finding suggests that the teachers' perceived that there is not much different change in their ICT integration to perform those four tasks before and after the MCO period.

However, both sets of data for three of the categories namely communicate with students and parents $(\mathrm{t}=3.667, p=0.001)$, to monitor and evaluate children progress or performance ( $\mathrm{t}=4.068, p=0.000)$, and to provide and prepare online work or assignment $(\mathrm{t}=6.771, p=0.000)$ are statistically significantly

Table 2. Paired-samples T test for the impact of ICT use (before MCO and after MCO).

\begin{tabular}{|c|c|c|c|c|c|c|c|c|c|}
\hline & & \multicolumn{5}{|c|}{ Paired Differences } & \multirow{3}{*}{$\mathrm{t}$} & \multirow{3}{*}{ df } & \multirow{3}{*}{$\begin{array}{c}\text { Sig. } \\
\text { (2-tailed) }\end{array}$} \\
\hline & & \multirow[t]{2}{*}{ Mean } & \multirow[t]{2}{*}{ S.D. } & \multirow{2}{*}{$\begin{array}{l}\text { Std. Error } \\
\text { Mean }\end{array}$} & \multicolumn{2}{|c|}{$\begin{array}{l}95 \% \text { Confidence Interval } \\
\text { of the Difference }\end{array}$} & & & \\
\hline & & & & & Lower & Upper & & & \\
\hline prepare lesson and reports & Before MCO-After MCO & 0.018 & 0.733 & 0.099 & -0.180 & 0.216 & 0.184 & 54 & 0.855 \\
\hline $\begin{array}{l}\text { access internet to search teaching } \\
\text { material }\end{array}$ & Before MCO-After MCO & 0.073 & 0.742 & 0.100 & -0.128 & 0.273 & 0.727 & 54 & 0.470 \\
\hline $\begin{array}{l}\text { communicate with students and } \\
\text { parents }\end{array}$ & Before MCO-After MCO & 0.455 & 0.919 & 0.124 & 0.206 & 0.703 & 3.667 & 54 & 0.001 \\
\hline $\begin{array}{l}\text { create teaching aids with the } \\
\text { computer }\end{array}$ & Before MCO-After MCO & 0.109 & 0.685 & 0.092 & -0.076 & 0.294 & 1.181 & 54 & 0.243 \\
\hline $\begin{array}{l}\text { to monitor and evaluate children } \\
\text { progress or performance }\end{array}$ & Before MCO-After MCO & 0.418 & 0.762 & 0.103 & 0.212 & 0.624 & 4.068 & 54 & 0.000 \\
\hline $\begin{array}{l}\text { to make presentation slides/ } \\
\text { delivery }\end{array}$ & Before MCO-After MCO & 0.091 & 0.701 & 0.905 & -0.009 & 0.280 & 0.962 & 54 & 0.341 \\
\hline $\begin{array}{c}\text { to provide and prepare online } \\
\text { work or assignment }\end{array}$ & Before MCO-After MCO & 0.927 & 1.016 & 0.137 & 0.653 & 1.202 & 6.771 & 54 & 0.000 \\
\hline
\end{tabular}


different. This finding suggests that the teachers perceived differences in changes in their ICT use to perform those three tasks before the MCO period compared to after the MCO period.

Thus, the null hypothesis that there is no relationship between Malaysian primary teachers' perceptions of ICT use in their level one (Primary One, Primary Two, and Primary Three) CEFR lessons before and after MCO cannot be rejected to a certain extent based on the above findings.

\subsection{Findings on Challenges to ICT Use in ESL (CEFR) Lessons}

To determine the challenges to ICT use in ESL (CEFR) lessons, one item was used (open-ended question), and the analysis was in words and frequency. Table 3 shows the themes and sub-themes of main challenges to ICT use in ESL (CEFR) lessons.

Table 3. Themes and sub-themes of main challenges to ICT use in ESL (CEFR) lessons.

\begin{tabular}{|c|c|c|c|}
\hline Themes & Sub-themes & $\begin{array}{l}\text { No. of } \\
\text { respondents }\end{array}$ & $(\%)$ \\
\hline $\begin{array}{l}\text { Lack in ICT } \\
\text { infrastructure }\end{array}$ & $\begin{array}{l}\text { Limited internet access in schools, personal and } \\
\qquad \text { parents/pupils): }\end{array}$ & 27 & 49.1 \\
\hline $\begin{array}{l}\text { Lack in ICT } \\
\text { infrastructure }\end{array}$ & $\begin{array}{l}\text { Lack of ICT facilities (in schools, personal and } \\
\text { parents/pupils): }\end{array}$ & 11 & 20 \\
\hline Lack of basic facility & Unstable electrical supply & 2 & 3.6 \\
\hline Teachers' attitude & $\begin{array}{c}\text { Time-consuming to set up the ICT facilities and } \\
\text { prepare the teaching materials (PPT slides and online } \\
\text { materials) }\end{array}$ & 4 & 7.3 \\
\hline Teachers' attitude & Additional work & 2 & 3.6 \\
\hline Pupils' engagement & Pupils' participation; did not do the task given & 2 & 3.6 \\
\hline Parents' ability & Unable to teach using the materials given. & 1 & 1.8 \\
\hline
\end{tabular}

Based on the data in Table 3 on themes and sub-themes of primary challenges to the ICT integration in CEFR lessons which was the outcome after the analyzed and coded process of the results obtained from the open-ended question in the questionnaire, $27 \%$ or $49.1 \%$ of the respondents have voiced out their thought about lacking in ICT infrastructure which is the limitation of internet access either in schools, personal or among the parents or the pupils that curb them from fully utilizing ICT in their CEFR lessons before and after the implementation of MCO. This issue is thus seen as the first and significant obstacle. Some of their responses concerning this issue are as follow:

"The level performance of internet in my school that lack of people can utilize frequently and cannot make e-learning platform to my students" (Teacher 1)

"Poor internet speed n connection" (Teacher 23)

“... internet coverage is very poor that we can't get more than half of the 
parents and pupils to get the exercises given during or after MCO" (Teacher 34)

"Some pupils cannot be accessed when giving homework online" (Teacher 38)

"Indeed, internet coverage was and still very poor in rural area" (Teacher 40)

"I have limited connectivity at home, during MCO of course that was the main obstacle, after MCO, also a problem as I need internet to using and making lesson for CEFR" (Teacher 41)

The second challenge raised by the teachers ( 11 or $20 \%$ of the respondents) is the lack of infrastructure in the ICT facilities either in schools, personal or among the parents or the pupils. Some of their responses to this issue are as follow:

"Had to share 1 LCD projector with other classes" (Teacher 46)

"Insufficient ICT facilities like computer \& LCD projector" (Teacher 55)

"I can't contact my students' parents to monitor my students' progress in online learning because of phone connection difficulties" (Teacher 45)

The third challenge raised by the teachers ( 2 or $3.6 \%$ of the respondents) is the lack of a primary facility with an unstable electrical supply. This challenge is probably because 5 out of 31 primary schools in this district still depend on generator sets as their main electrical supply and thus resorted to this issue. Their responses to this issue are as follow:

"No electricity" (Teacher 31 and Teacher 37)

The fourth challenge is related to the teachers' attitude as they are concerned about setting up the ICT facilities and preparing the teaching materials using ICT, such as PowerPoint slides and online materials. To them, it is time-consuming and therefore chooses not to use ICT in their teaching or classes. Among their responses to this issue are as follow:

"i. Setting up projector in the classroom takes time. ii. Required much time to prepare the PPT slides or find online materials" (Teacher 12)

"Time consuming to set up the ICT tools for lessons such as LCD projector as there is only one and it is shared with the whole school" (Teacher 32)

"Takes time to set up the TV" (Teacher 38)

The fifth challenge is also related to the teachers' attitude as they perceived that it is an "additional work" (Teacher 31 and Teacher 38)

The sixth challenge is related to the pupils' engagement as one of the teachers has reported that his/her pupils did not do the tasks given online (Teacher 39). Another teacher (Teacher 27) also reported on pupils' participation as the obstacle. During MCO, both teachers and pupils are encouraged to practice online learning as a norm to continue their lessons even in their home. Nevertheless, due to the obstacles faced by both parties, it is undeniable that pupils will tend to 
not turn up during the online lesson, complete the tasks given to them and submit the assignments as instructed.

The seventh (last) challenge raised by one of the teachers is regarding the parents' ability. Since the pupils spend more time at home, they need to complete the tasks given by their teachers either online or printed materials with their parents' supervision. Thus, the response given by the teacher as the respondent is as follow:

"Parents could not teach using the materials given" (Teacher 39).

Nevertheless, two respondents (3.6\%) have a different view as they did not face any obstacle in using ICT in teaching their CEFR classes. Although they represent a smaller number of respondents, it gives a lively ambience to the population's education system.

\section{Discussion}

\subsection{Malaysian Primary Teachers' Perception on ICT Use in ESL (CEFR) Lessons before MCO and after the MCO Period}

The TAM model emphasizes the two key elements that could influence one state of mind towards another technology: Perceived Usefulness (PU) and Perceived Ease of Use (PEoU). At present, the method where information is gained, achieved, and construed has transformed due to the revolution of ICT (Hernandez, 2017; Aguilar, 2012). Based on the obtained findings on ICT use in ESL (CEFR) lessons (Before MCO and After MCO) (refer to Table 2), it is determined that the Malaysian primary teachers, particularly in Lawas, Sarawak perceived that there are a small number of differences in the ICT use to perform those four tasks: preparing lessons and reports, accessing the internet to search for teaching materials, creating computer teaching aids, and making presentation slides/delivery before and after the MCO period in the ESL (CEFR) level one (Primary one, Primary Two and Primary Three) lessons. In the study by Kamaruddin et al. (2017), the teachers' ICT integration's highest mean score is 2.68 (activity: prepare lessons and reports). Thus according to Parra (2012), technology's inexhaustible impact has also influenced the teacher's role. These findings, therefore, indicate the commitment of teachers to carry out their core business in teaching, particularly in the preparation of their ESL lessons and reports supported by ICT, and it has become part of their routine as English teachers to carry out the tasks. Moreover, this favorable impression is based on the fact that teachers have witnessed and experienced a wide range of benefits from using ICT in educational activities. Thus, the above result shows that the ESL teachers' perception of ICT use falls under Perceived Usefulness.

According to Bernama (2020), to determine the scope of practice of administrators, teachers, parents, and students in ensuring the quality of teaching and learning, Malaysian Ministry of Education has established guidelines for implementing teaching and learning for the Movement Control Order (MCO) period. 
Teachers could utilize different online and relevant social media sites to prepare and distribute assignments or homework. Besides, teachers are granted flexibility about teaching and learning time, mentoring strategies, exercise checks, tasks, and homework. The changes made by Malaysian Ministry of Education have had an impact on teacher perceptions of ICT use at the ESL level one (Primary One, Primary Two and Primary Three) CEFR lessons (Before and After MCO Period) in terms of communicating with students and parents, monitoring and evaluating children's progress or performance, and providing and preparing online work or assignment. The whole process is done to ensure that both the English teachers and the pupils can continue the teaching and learning process despite having it in a different learning environment-at home during the MCO period. Besides, teaching progress depends on the gradual incorporation of ICTs (Poudel, 2018). Therefore, the above result shows that the perception of the ESL teachers to ICT use falls under the category of Perceived Ease of Use.

Conversely, due to the indirect impact of the MCO period, other barriers such as the lack of ICT infrastructure and basic facilities, the attitude of teachers, the involvement of pupils, and the ability of parents are also considered to influence the ICT use among the teachers based on the scenario in teaching primary level one (Primary One, Primary Two and Primary Three) ESL (CEFR) classes.

\subsection{Challenges to ICT Use in ESL Lessons among Malaysian Primary Teachers (before MCO and after MCO Period)}

Based on the Theory of Planned Behavior by Ajzen (2000), which was reformulated according to the Theory of Expected Behavior (TpB), it is believed that this study has shown the impact of one's belief on ICT's intended use. This theory acknowledges that all behaviors are rational, although they are not always based on the analytical thinking that people act. As per this study, it was discovered that there are several challenges to ICT use in ESL lessons among Malaysian Primary Teachers (Before MCO and After the MCO period) based on the perspectives of the teachers in Lawas, Sarawak. The challenges are as follows:

\subsubsection{Lack of ICT Infrastructures and Basic Facilities}

According to Mirzajani et al. (2016), teachers would not have been motivated to use ICT in the classroom unless the school had good tools and appropriate educational equipment, such as computer software and hardware. To support the operation of the ICT tools, undoubtedly even the most commonly used ICT tools in teaching and learning, such as desktops or laptops, mobile phones, and speakers, required basic facilities and the power supply. Shortage of facilities to be used by teachers and pupils in schools and high cost of maintenance issues are also another co-factor or challenge for the teachers from integrating ICT into their lessons. Most researchers report that the most fundamental and essential aspects are the power source and network connectivity. So, the least developed countries are forced to concentrate on building ICT-integrated classrooms in urban environments (Cha et al., 2020). 
The respective stakeholders, such as the local energy development company, Sarawak Energy Berhad (SESCO), should work proactively to provide more support, with the cooperation from the policymaker-Malaysian government and Ministry of Education to allocate more funds to the respective schools and their surroundings. It is to ensure the existence of a 24-hour power supply for the betterment of society. Although there are many exciting and valuable resources on the Malaysian version of CEFR ESL lessons available on the internet, particularly on the YouTube channel, a lack of accessibility prevents them from doing so. Malaysian National Security Council imposed the government's movement restrictions on the Malaysian in response to the COVID-19 pandemic exacerbated the situation, as pupils could not travel to the nearest town for a better internet connection to complete their remote learning.

\subsubsection{Teachers' Attitude}

Teachers' attitude to ICT integration in the ESL (CEFR) lesson is perceived as time-consuming and additional work. This obstacle would probably also be caused by the ESL teachers' anxiousness to complete the syllabus from another perspective. Thus, considering time management to complete the lesson within the time frame is their priority. Habibu et al. (2012) identify eight factors that limit ICT use in the teaching and learning process, and one of them is the time limitation. Pham et al. (2019) also supported the finding as their study has discovered four issues and challenges, and one of them is the shortage of time in class. Narinasamy and Wan Mamat (2013) state that the deficiency of time faced in completing the syllabus resulted in discarding the ICT in classroom teaching.

Furthermore, English is taught as a major subject in all public national primary schools in Malaysia. It is one of the subjects that are given special attention to be assessed and reported in the School-Based Assessment (SBA). However, no examinations are given to students from Primary One to Primary Three officially since 2018 within the country. Accordingly, the conflict between fulfilling their core business of teaching and putting extra effort in their teaching by implementing ICT should be thoughtfully addressed. As a result of this finding, ESL teachers' attitudes toward ICT use in the lessons should be considered, regardless of whether they are English option or non-English option. Teachers' attitudes toward technology and technology teaching in technology education reflected an aspect of teachers' attitudes that influences students' attitudes, as well as teachers' professional knowledge (Rohaan et al., 2008).

\subsubsection{Pupils' Engagement}

Yunus et al.'s (2013) study has revealed the drawbacks of ICT incorporation in the classroom that need to be taken into account, particularly by teachers who are experiencing difficulty, for instance, in-class discipline and interruption. Based on the study findings, it is found that the ESL teachers are having a hard time with their pupils' engagement as the pupils have the tendency not to turn in the given tasks. During the MCO period, tasks are assigned using either ICT or 
printed materials, or a combination of both (ICT and printed materials) for specific schools. Thomas \& Fong (2020) highlight that due to technical errors such as broadcast issues and sound problems, a third of them do not do the tasks given. This scenario might occur due to specific reasons. Apart from issues with internet access and a lack of ICT devices, the stress caused by various homework subjects and the learners' adaptation to home-based learning should be considered. This statement is, therefore, consistent with the Pope's (2020) findings on homework.

Furthermore, the learners are non-native English speakers from a community where English communication is rarely practiced. The rural students tend to mix, combine, misuse, or apply both rules and linguistic comprehension of the languages into writing without realizing it while learning the second language (Harun \& Abdullah, 2020). It thus necessitates the pupils' interest and determination to acquire and learn the language itself and their reliance on their English teachers to guide them through a proper lesson and homework.

ICT can facilitate knowledge accessibility and comprehension, helping the self-exploration and self-study of the learners. By turning the environment into learner-centered learning and encouraging deep understanding, the use of multiple alternatives provided by ICTs improves teaching and learning (Mbodila et al., 2013). Yet, pupils' participation in online learning is reported as one of the teachers' challenges under pupils' engagement. Wise et al. (2013) discover that only certain learners can participate in online courses effectively. Thomas and Fong (2020) support the finding by mentioning the student response has not been very positive because some students do not react or respond. Unavailability of ICT and internet connectivity have been identified as the main hindrance by the teachers to the pupils' engagement. Thus, the initiative was taken by some of the local teachers to have a mix-mode teaching method, namely homework delivery, and "ruai" classrooms are seen to be an effective way to keep their pupils learning on-going. Besides, because of the rural pupils' lack of command of the English language, as supported by Juin (2016), the majority of Malaysian rural ESL students have low levels of proficiency. Because of that, it indirectly could demotivate some of them from completing the English-language task, local teachers' initiatives, as mentioned above, possibly the best option for this group of pupils during the COVID-19 pandemic outbreak, rather than relying on ICT. At the same time, it also shows their professionalism and total dedication to enhancing the society they serve.

\subsubsection{Parents' Ability}

Based on the study's findings, it is discovered that another factor is related to the capacity of parents, in which case the parents are unable to teach their children using the materials given. As one of the consequences of closing schools during the COVID-19 pandemic, Espino-Díaz et al. (2020) discover that parents' low educational level causes inadequate training among parents for distance learning. The most underprivileged families are, to a greater extent, harmed. Azahar 
(2020) supports the statement by pointing the scenario in Malaysia, whereby even with Internet access improving the rating from 87 per cent in 2018 to 90.1 per cent in 2019. Due to high and low level of confidence in equipment prices, inadequate knowledge and skills to practice it, the remaining underprivileged households were unable to access the Internet at home.

Parents, like teachers, play an essential role in the educational system and are thus recognized as important stakeholders. In school, pupils gain the opportunity to have face-to-face guidance with their teachers when completing the exercises or tasks given to them in the classroom. Some of them may not be able to provide or own ICT facilities at home, including a smartphone, because of their lack of economic background, for an instant. The educational experience among parents is another aspect that leads to this problem: the parents' inability. Both students and parents believe it is a significant issue because they believe the questions as set solely to consider HOTS issues ("Years of Mismanaged Change in Education Must End", 2018).

Furthermore, based on the study's locality, the language barrier among the parents is another factor that needs to be considered. As mentioned in 3.2, one of the prevalent ethnic groups in the field of study (Lawas, Sarawak) is the Lun Bawang, mainly distributed in Limbang districts, such as Trusan, Ba Kelalan, Long Semadoh and Long Luping (Kata Malaysia, 2020). While English is taught in school as a second language, it could still be an 'alien' language for parents, particularly those living in a community with only a minority of English speakers. Without a doubt, English may be poorly acquired by parents because opportunities to practice the language are not as frequent as opportunities to practice their mother tongue in daily conversations with their children and community. Maya (2020) supports this by affirming that the transition to distance learning due to the COVID-19 pandemic outbreak was much more troublesome for parents with English language learning than predicted. The parents will usually give up on the homework and wait for the teacher to guide their pupils. Those dedicated and compassionate parents will seek assistance from the teacher themselves or through their children. Nevertheless, to ensure the children are not left behind with their studies, the parents who own ICT tools such as mobile phones and laptops at home should possess a positive attitude towards ICT use and show moral support. At the same time, they should keep an eye on their children while utilizing the tools during their learning session, specifically to curb the children's involvement in illegal activities to protect the child's rights.

\section{Conclusion and Recommendation}

The study aims to explore the Malaysian primary schools' teachers' perceptions and their challenges on the impact of ICT use in their level one (Primary One, Primary Two and Primary Three) ESL (CEFR) lessons. In general, the implementation of MCO during the COVID-19 pandemic outbreak could also impact the teachers' perception of ICT use in their ESL lessons. Thus, it is consistent 
with the theory embedded in this study, namely the Theory of Acceptance model (TAM) and the Theory of Planned Behavior (Tpb) model. Based on the paired-sample T-test result, it is determined that there is no significant relationship between teachers' perception of ICT use during MCO and after the MCO period in performing the four tasks which are prepared lessons and reports, access internet to search teaching materials, create teaching aids with the computer, and to make presentation slides/delivery. Nevertheless, there is a significant relationship between teachers' perception of ICT use during MCO and after the MCO period in performing the other three tasks, communicating with students and parents, monitoring and evaluating children's progress or performance, and providing and preparing online work or assignment. This finding indicates that the teachers use ICT in their ESL lessons more frequently after the MCO period to accomplish those particular tasks. Still, the result differs because of the need to adapt the learning delivery environment to suitability and flexibility, in addition to complying with the guidance given by Malaysian Ministry of Education, in particular for lessons conducted during the MCO period. As a result, primary English teachers should take decisive action to incorporate ICT into their classes and maintain a positive attitude toward ICT integration. It is undeniably beneficial to both teachers and students. The potential benefits are ineffective learning per se and in the other aspects of learning management, such as the preparation and reporting stages.

Finally, four significant challenges to ICT use in ESL lessons have been outlined (both before and after MCO implementation). The challenges are lack of ICT infrastructure and basic facilities, teachers' attitude, pupils' engagement, and parents' ability. Firstly, in terms of lack of ICT infrastructure and basic facilities, the issue includes the limitation of internet access either in schools, personal or between parents or pupils, and the lack of stable electrical supply. This study discovers the factor as one of the most significant impediments to ESL primary teachers fully integrating ICT into their level one CEFR lesson before and after implementing the MCO. Secondly, in terms of the attitude of teachers, this study discovers that teachers are mindful of the time needed to set up ICT facilities and prepare teaching materials using ICT, such as PowerPoint slides and online materials. Teachers perceived it as time-consuming and additional work, resulting in ICT not being integrated into their CEFR lessons. Next, in terms of pupils' engagement, the finding highlights submitting online tasks to pupils and pupils' participation in online classes as the issues. Hence, the involvement of pupils in lessons could determine teachers' perception of ICT integration in their lessons, especially when it comes to distance learning during the MCO period. Lastly, this study discovers that parents who were unable to teach their children to use the materials provided by teachers. The factor could also influence the perception of ESL primary teachers by integrating ICT into their distance CEFR lessons.

It will take close collaboration with various education stakeholders and com- 
mitment from various non-government organizations to close the gap in ICT use in ESL lessons among teachers across the country and improve the quality of social life. It is crucial to meet the basic requirements for integrating ICT into the educational system. Teachers in rural areas, in particular, require more assistance in this case because they have faced numerous challenges in incorporating ICT into their ESL lessons. As evidenced by classes held during the MCO period, teachers are encouraged to work from home and students are forced to learn online. It is hoped that the experience of distance learning during the COVID-19 pandemic and the MCO period, which affected most schools in Malaysia and around the world, will serve as a wake-up call for society to work hand-in-hand with teachers to raise awareness of the value of ICT in education.

However, because this study is based on a small sample size, the result cannot generalize to all primary English teachers in Malaysia. As a result, more respondents from across the country are needed for a more in-depth approach, such as massive distribution of questionnaire and an interview on teachers' perceptions and challenges. By considering an entire qualitative-based research method to be implemented, other researchers too could replicate the research.

\section{Conflicts of Interest}

The authors declare no conflicts of interest regarding the publication of this paper.

\section{References}

"Years of Mismanaged Change in Education Must End" (May 22, 2018). Years of Mismanaged Change in Education Must End. The Star. https://www.thestar.com.my/opinion/letters/2018/05/22/years-of-mismanaged-changein-education-must-end

Aguilar, M. (2012). Aprendizaje y Tecnologías de Información y Comunicación: Hacia nuevos escenarios educativos [Learning and Information and Communication Technologies: Towards New Educational Scenarios]. Revista Latinoamericana de Ciencias Sociales, Niñez y Juventud (Latin American Journal of Social Sciences, Children and Youth), 10, 801-811.

Ajzen, I. (1988). Attitudes, Personality, and Behavior. Chicago, IL: Dorsey Press.

Ajzen, I. (2000). TpB Diagram. The Theory of Planned Behavior. http://people.umass.edu/aizen/tpb.diag.html

Ajzen, I. (2019). Theory of Planned Behavior Diagram. https://people.umass.edu/aizen/tpb.diag.html\#null-link

Ajzen, I., \& Fishbein, M. (1980). Understanding Attitudes and Predicting Social Behavior. Englewood Cliffs, NJ: Prentice-Hall.

Alshare, K. A., Freeze, R., \& Kwun, O. (2009). Student Intention to Use Expert Systems: An Exploratory Study. Journal of Computer Information Systems, 49, 105-113.

Azahar, N. S. H. (2020, April 14). Distant Learning a New Normal in Education. New Straits Times.

https://www.nst.com.my/opinion/letters/2020/04/584165/distant-learning-new-normal -education 
Baker, R. K., \& White, K. M. (2010). Predicting Adolescents' Use of Social Networking Sites from an Extended Theory of Planned Behaviour Perspective. Computers in $\mathrm{Hu}$ man Behavior, 26, 1591-1597. https://doi.org/10.1016/j.chb.2010.06.006

Baker-Eveleth, L., Eveleth, D. M., O’Neill, M., \& Stone, R. W. (2006). Enabling Laptop Exams Using Secure Software: Applying the Technology Acceptance Model. Journal of Information Systems Education, 17, 413-420.

Bernama (2020, March 27). Education Ministry Readying Guidelines on Teaching, Learning during MCO. Malay Mail.

https://www.malaymail.com/news/malaysia/2020/03/27/education-ministry-readying-g uidelines-on-teaching-learning-during-mco/1850854

Cha, H., Park, T., \& Seo, J. (2020). What Should Be Considered When Developing ICT-Integrated Classroom Models for a Developing Country? Sustainability, 12, 1-19. https://doi.org/10.3390/su12072967

Cheok, M. L., Wong, S. L., Ayub, A. F., \& Mahmud, R. (2017). Teachers' Perceptions of E-Learning in Malaysian Secondary Schools. Malaysian Online Journal of Educational Technology, 5, 20-33.

Davis, F. D., Bagozzi, R. P., \& Warshaw, P. R. (1989). User Acceptance of Computer Technology: A Comparison of Two Theoretical Models. Management Science, 35, 982-1003. https://doi.org/10.1287/mnsc.35.8.982

Davis, R., \& Wong, D. (2007). Conceptualizing and Measuring the Optimal Experience of the eLearning Environment. Decision Sciences Journal of Innovative Education, 5, 97-126. https://doi.org/10.1111/j.1540-4609.2007.00129.x

Emad, H., El-Bakry, H. M., \& Aem, A. (2016). A Modified Technology Acceptance Model for Health Informatics. International Journal of Artificial Intelligence and Mechatronics, 4, 153-161.

Espino-Díaz, L., Fernandez-Caminero, G., Hernandez-Lloret, C., Gonzalez-Gonzalez, H., \& Alvarez-Castillo, J.-L. (2020). Analyzing the Impact of COVID-19 on Education Professionals. Toward a Paradigm Shift: ICT and Neuroeducation as a Binomial of Action. Sustainability, 12, 1-10. https://doi.org/10.3390/su12145646

Etikan, I., Musa, S. A., \& Alkassim, R. S. (2016). Comparison of Convenience Sampling and Purposive Sampling. American Journal of Theoretical and Applied Statistics, 5, 1-4. https://doi.org/10.11648/j.ajtas.20160501.11

Fortin, D. R. (2000). Clipping Coupons in Cyberspace: A Proposed Model of Behavior for Dealprone Consumers. Psychology \& Marketing, 17, 513-534. https://doi.org/10.1002/(SICI)1520-6793(200006)17:6<515::AID-MAR5>3.0.CO;2-B

George, J. F. (2002). Influences on the Intent to Make Internet Purchases. Internet Research, 12, 165-180. https://doi.org/10.1108/10662240210422521

Goeke, R. J., \& Faley, R. H. (2007). Leveraging the Flexibility of Your Data Ware House. Communications of the ACM, 50, 107-111. https://doi.org/10.1145/1290958.1290970

Ha, S., \& Stoel, L. (2009). Consumer E-Shopping Acceptance Antecedents in a Technology Acceptance Model. Journal of Business Research, 62, 565-571. https://doi.org/10.1016/j.jbusres.2008.06.016

Habibu, T., Abdullah-AL-Mamun, M., \& Clement, C. (2012). Difficulties Faced by Teachers in Using ICT in Teaching-Learning at Technical and Higher Educational Institutions of Uganda. International Journal of Engineering Research \& Technology (IJERT), 1, 1-9.

Harun, H., \& Abdullah, M. K. K. (2020). Errors in Writing Made by Malaysian Rural Primary School Pupils. Studies in English Language and Education, 7, 438-456. 
https://doi.org/10.24815/siele.v7i2.17009

Hernandez, R. M. (2017). Impact of ICT on Education: Challenges and Perspectives. Propósitos y Representaciones (Purposes and Representations), 5, 325-347. https://doi.org/10.20511/pyr2017.v5n1.149

Ismail, I. S. (2019, June 27). 3 syarikat ISP bekal perkhidmatan talian Internet ke sekolah mulai 1 Julai [3 ISP Companies Supply Internet Line Services to Schools from 1 July]. Berita Harian.

https://www.bharian.com.my/berita/nasional/2019/06/578757/3-syarikat-isp-bekal-per khidmatan-talian-internet-ke-sekolah-mulai-1

Juin, J. K. (2016). Exploring the Use of the Learning Contract among Low English Proficiency Rural Learners. The English Teacher, 45, 114-125.

Kadian, A., Rani, K., \& Devi, S. (2019). Communicative Approach in Technology-Enhanced ESL Teaching-Learning. International Journal of Research in Engineering, IT and Social Science, 9, 288-292.

Kamaruddin, K., Che Abdullah, C. A., \& Idris, M. N. (2017). Integrating ICT in Teaching and Learning: A Preliminary Study on Malaysian Private Preschool. International Journal of Academic Research in Business and Social Sciences, 7, 1236-1248. https://doi.org/10.6007/IJARBSS/v7-i11/3561

Karim, K. N. (2020, March 28). Edu Ministry Introduces Guidelines on Online Teaching, Learning Platforms. New Straits Times. https://www.nst.com.my/news/nation/2020/03/578945/edu-ministry-introduces-guidel ines-online-teaching-learning-platforms

Kata Malaysia (2020, May 4). LUN BAWANG DI BORNEO [Lun Bawang in Borneo]. https://katamalaysia.my/culture/lun-bawang-di-borneo/

Kim, K., \& Bonk, C. J. (2006). The Future of Online Teaching and Learning in Higher Education: The Survey Says. Educause Quarterly, 29, 22-30.

Knabe, A. (2012). Applying Ajzen's Theory of Planned Behavior to a Study of Online Adoption in Public Relations Education. Dissertation (1934 -). Dissertation for Degree of Doctor of Philosophy, Faculty of the Graduate School. Milwaukee, Wisconsin: Marquette University.

https://epublications.marquette.edu/cgi/viewcontent.cgi? article $=1186 \&$ context $=$ dissert ations mu

Lee, J., Cerreto, F. A., \& Lee, J. (2010). Theory of Planned Behavior and Teachers' Decisions Regarding Use of Educational Technology. Educational Technology \& Society, 13, 152-164.

Leong, A. C. H., Abidin, M. J. Z., \& Saibon, J. (2019). Learners' Perceptions of the Impact of Using Digital Storytelling on Vocabulary Learning. Teaching English with Technology, 19, 3-36.

Lin, H. F. (2008). Antecedents of Virtual Community Satisfaction and Loyalty: An Empirical Test of Competing Theories. CyberPsychology \& Behavior, 11, 138-144. https://doi.org/10.1089/cpb.2007.0003

Lin, P. C., \& Chou, Y. H. (2009). Perceived Usefulness, Ease-of-Use and Usage of Citation Database Interfaces: A Replication. The Electronic Library, 27, 31-42.

https://doi.org/10.1108/02640470910934579

Ling, S. (2020, April 25). Teacher Goes the Extra Mile to Send Learning Materials to Rural Students. The Star.

https://www.thestar.com.my/news/nation/2020/04/25/teacher-drives-hours-to-send-lea rning-materials-to-rural-students 
Mahdum, M., Hadriana, H., \& Safriyanti, M. (2019). Exploring Teacher Perceptions and Motivations to ICT Use in Learning Activities in Indonesia. Journal of Information Technology Education: Research, 18, 293-317.

Maya, V. (2020, August 21). Language Barriers Limit Parents' Ability to Assist Their Children with Remote Learning.

https://www.talonmarks.com/top-stories/2020/08/21/language-barriers-limit-parents-a bility-to-assist-their-children-with-remote-learning/

Mbodila, M., Jones, T., \& Muhandji, K. (2013). Integration of ICT in Education: Key Challenges. International Journal of Emerging Technology and Advanced Engineering, 3, 515-520.

Ministry of Education (2015). Malaysia Education for All Decade Review Report 2000-2015. Putrajaya: Ministry of Education.

Mirzajani, H., Mahmud, R., Mohd Ayub, A. F., \& Su, L. W. (2016). Teachers' Acceptance of ICT and Its Integration in the Classroom. Quality Assurance in Education, 24, 26-40. https://doi.org/10.1108/QAE-06-2014-0025

Moss, N. D., O'Connor, E. L., \& White, K. M. (2010). Psychosocial Predictors of the Use of Enhanced Podcasting in Student Learning. Computers in Human Behavior, 26, 302-309. https://doi.org/10.1016/j.chb.2009.10.012

Muslem, A., Yusuf, Y. Q., \& Juliana, R. (2018). Perceptions and Barriers to ICT Use among English Teachers in Indonesia. Teaching English with Technology, 18, 3-23.

Narinasamy, I., \& Wan Mamat, W. H. (2013). Utilization of ICT by Moral Education Teachers. The Malaysian Online Journal of Educational Technology, 1, 44-53.

Parra, C. (2012). TIC, conocimiento, educación y competencias tecnológicas en la formación de maestros [ICT, Knowledge, Education and Technological Skills in Teacher Training]. Nómadas (Nomads), 36, 145-159.

Pham, T. T. N., Tan, C. K., \& Lee, K. W. (2019). Issues and Challenges in Using ICT for Teaching English in Vietnam. CALL-EJ, 20, 140-155.

Pope, D. (2020, August 27). Does Homework Work? ASCD Express, 15. http://www.ascd.org/ascd-express/vol15/num24/making-homework-work.aspx

Poth, C., \& Munce, S. E. P. (2020). Commentary-Preparing Today's Researchers for a Yet Unknown Tomorrow: Promising Practices for a Synergistic and Sustainable Mentoring Approach to Mixed Methods Research Learning. International Journal of Multiple Research Approaches, 12, 56-64. https://doi.org/10.29034/ijmra.v12n1commentary

Poudel, G. P. (January 7, 2018). Integrating ICTs in English Language Teaching: Teachers' Perception, Strategies and Challenges. https://neltaeltforum.wordpress.com/2018/01/07/integrating-icts-in-english-language-t eaching-teachers-perception-strategies-and-challenges/

Robinson, R. P., \& Doverspike, D. (2006). Factors Predicting the Choice of an Online Versus a Traditional Course. Teaching of Psychology, 33, 64-68.

https://doi.org/10.1207/s15328023top3301 10

Rohaan, E. J., Taconis, R., \& Jochems, W. M. G. (2008). Reviewing the Relations between Teachers' Knowledge and Pupils' Attitude in the Field of Primary Technology Education. International Journal of Technology and Design Education, 20, 15-26. https://doi.org/10.1007/s10798-008-9055-7

Rusdin, N. M. (2018). Teachers' Readiness in Implementing 21st Century Learning. International Journal of Academic Research in Business and Social Sciences, 8, 1271-1284. https://doi.org/10.6007/IJARBSS/v8-i4/4270 
Silviyanti, T. M., \& Yusuf, Y. Q. (2015). EFL Teachers' Perceptions on Using ICT in Their Teaching: To Use or to Reject? Teaching English with Technology, 15, 29-43.

Thomas, J., \& Fong, D. R. (2020, April 3). Playing Catch-Up with Online Learning during MCO. FMT.

https://www.freemalaysiatoday.com/category/nation/2020/04/03/playing-catch-up-wit h-online-learning-during-mco/

Wise, A. F., Zhao, Y., \& Hausknecht, S. N. (2013). Learning Analytics for Online Discussions: A Pedagogical Model for Intervention with Embedded and Extracted Analytics. In LAK 2013: 3rd International Conference on Learning Analytics and Knowledge (pp. 48-56). (ACM International Conference Proceeding Series). https://doi.org/10.1145/2460296.2460308

Yunus, M. M. (2018). Innovation in Education and Language Learning in $21^{\text {st }}$-Century. Journal of Sustainable Development Education and Research, 2, 33-34. https://doi.org/10.17509/jsder.v2i1.12355

Yunus, M. M., Nordin, N., Salehi, H., Embi, M. A., \& Salehi, Z. (2013). The Use of Information and Communication Technology (ICT) in Teaching ESL Writing Skills. English Language Teaching, 6, 1-8. https://doi.org/10.5539/elt.v6n7p1

Zaremohzzabieh, Z., Samah, B. A., Muhammad, M., Omar, S. Z., Bolong, J., Hassan, M. S., \& Shaffril, H. A. M. (2015). A Test of the Technology Acceptance Model for Understanding the ICT Adoption Behavior of Rural Young Entrepreneurs. International Journal of Business and Management, 10, 158-169.

https://doi.org/10.5539/ijbm.v10n2p158 